\title{
Aspects of nitrogen use efficiency of cauliflower II. Productivity and nitrogen partitioning as influenced by $N$ supply
}

\author{
H. KAGE*, C. ALT ANd H. STÜTZEL \\ Institute for Vegetable and Fruit Crops, University of Hannover, Herrenhäuser Str. 2, \\ D-30419 Hannover, Germany
}

(Revised MS received 29 July 2003)

\begin{abstract}
SUMMARY
Based on studies concerning dry matter (DM) partitioning, DM production, root growth, nitrogen (N) contents of cauliflower organs and soil nitrate availability (first part of the paper Kage et al. $2003 \mathrm{~b}$ ), an integrated simulation model for the cauliflower/soil system is constructed, parameterized and evaluated.

Dry matter production of cauliflower is described and predicted using a simple light use efficiency $(L U E)$ based approach assuming a linear decrease of light use efficiency with increasing differences between actual, $N C A_{\text {Prot }}$, and 'optimal', $N C A o p t_{\text {Prot }}$ area based leaf protein concentrations. For 2 experimental years the decline of $L U E$ with decreasing nitrogen concentration was at 0.82 and 0.75 $\left(\mathrm{g} \mathrm{DM} \times \mathrm{m}^{2} /(\mathrm{MJ} \times \mathrm{g} \mathrm{N})\right)$. Using the parameters obtained from the first experimental year shoot DM production data of cauliflower from five independent experiments with varied $\mathrm{N}$ supply containing intermediate harvests could be predicted with a residual mean square error $(R M S E)$ of $72 \mathrm{~g} / \mathrm{m}^{2}$ for intermediate harvest DM values ranging from about 50 to $900 \mathrm{~g} / \mathrm{m}^{2}$. Nitrogen uptake and partitioning of cauliflower was simulated using functions describing an organ size dependent decline of $\mathrm{N}$ content. Leaf nitrate was considered explicitly as a radiation intensity dependent pool, mobilized first under $\mathrm{N}$ deficiency. The curd was assumed to have a sink priority for nitrogen. The model predicted shoot $\mathrm{N}$ uptake including data of intermediate harvest with a $R M S E$ of $2.4 \mathrm{~g} / \mathrm{m}^{2}$ for intermediate harvest $\mathrm{N}$ values ranging from about 3 to $30 \mathrm{~g} / \mathrm{m}^{2}$. Nitrogen uptake of cauliflower at final harvest was correlated to final leaf number.

A scenario simulation was carried out to quantify seasonal variation in $\mathrm{N}$ uptake of cauliflower cultivars under unrestricted $\mathrm{N}$ availability. Due to variations in the length of the vernalization phase, simulated shoot $\mathrm{N}$ uptake ranged from about $260 \mathrm{~kg} \mathrm{~N} /$ ha for spring planted crops to about $290 \mathrm{~kg}$ $\mathrm{N} /$ ha for summer planted crops of the cultivar 'Fremont'. The cultivar 'Linday', which shows a more severe delay of vernalization under high temperatures, shows on average a larger shoot $\mathrm{N}$ uptake for summer planted crops of about $320 \mathrm{~kg} \mathrm{~N} / \mathrm{ha}$ and a much larger variation of shoot $\mathrm{N}$ uptake.
\end{abstract}

\section{INTRODUCTION}

One of the prerequisites for efficient nitrogen use within intensive cropping systems is to achieve a close agreement between crop $\mathrm{N}$ demand and supply (Stockdale et al. 1997). Nitrogen fertilization therefore should be adjusted to complement the $\mathrm{N}$ supply from the soil resources. Empirical methods to derive

* To whom all correspondence should be addressed. Present address: Institute of Crop Science \& Plant Breeding, University of Kiel, Hermann-Rodewald-Str. 6, D-24118 Kiel, Germany. Email: kage@pflanzenbau.uni-kiel.de
$\mathrm{N}$ fertilization recommendations, like the $N_{\min }$ method (Scharpf \& Wehrmann 1975), rely on a static analysis of yield response to total $\mathrm{N}$ supply from a larger group of experiments. Thereby the term $\mathrm{N}$ supply summarizes $\mathrm{N}$ fertilization and soil mineral nitrogen down to a soil depth that can be almost completely exhausted by the root system. This approach has been applied to cauliflower (Everaarts et al. 1996; Everaarts \& Van den Berg 1996) taking mineral nitrogen down to a depth of $60 \mathrm{~cm}$ into account. This method intrinsically considers $\mathrm{N}$ supply from mineralization of soil organic matter, but only as an average value of 
Table 1. Type of experiment, annual $(A)$, long term $(L T)$, usage for parameterization $(P)$ for evaluation $(E)$, year, planting and harvest dates, average incident photosynthetic active radiation and average temperature during the growth period of the cauliflower experiments used in the present study

\begin{tabular}{lccccccc}
\hline \hline Type & Usage & Year & $\begin{array}{c}\text { Planting } \\
\text { date }\end{array}$ & $\begin{array}{c}\text { Harvest } \\
\text { date }\end{array}$ & $\begin{array}{c}\text { Average I } \\
\left(\mathrm{MJ} / \mathrm{m}^{2} \text { per day }\right)\end{array}$ & $\begin{array}{c}\text { Average } \\
\text { temp. }\left({ }^{\circ} \mathrm{C}\right)\end{array}$ & $\begin{array}{c}\text { No. of N } \\
\text { treatments }\end{array}$ \\
\hline A & $\mathrm{P}$ & 1996 & 170 & 240 & $7 \cdot 78$ & $16 \cdot 08$ & 4 \\
A & $\mathrm{E}$ & 1997 & 190 & 258 & $7 \cdot 23$ & $18 \cdot 56$ & 4 \\
LT & $\mathrm{E}$ & 1994 & 97 & 185 & $8 \cdot 13$ & $13 \cdot 12$ & 2 \\
LT & $\mathrm{E}$ & 1994 & 207 & 293 & $5 \cdot 45$ & $14 \cdot 52$ & 2 \\
LT & $\mathrm{E}$ & 1995 & 94 & 187 & $7 \cdot 59$ & $12 \cdot 13$ & 2 \\
LT & $\mathrm{E}$ & 1995 & 200 & 291 & $6 \cdot 10$ & $16 \cdot 49$ & 2 \\
LT & $\mathrm{E}$ & 1996 & 100 & 189 & $7 \cdot 41$ & $12 \cdot 59$ & 2 \\
LT & $\mathrm{E}$ & 1996 & 200 & 284 & $6 \cdot 18$ & $14 \cdot 34$ & 2 \\
A & $\mathrm{E}$ & 1994 & 152 & 236 & $9 \cdot 24$ & $18 \cdot 31$ & 1 \\
\hline \hline
\end{tabular}

the experiments included in the analysis. Also the $\mathrm{N}$ demand of the crop is considered only as an average value over the range of the experimental conditions. The actual $\mathrm{N}$ demand of cauliflower, however, can differ substantially between different transplanting dates because a delayed vernalization may increase the growth duration (Wiebe 1980; Wurr et al. 1994; Kage \& Stützel 1999b).

Approaches based on mechanistic models may help to calculate $\mathrm{N}$ demand more precisely and thereby minimize amounts of residual soil nitrate and leaching losses of $\mathrm{N}$ from the soil/plant system. Such a model-based procedure for calculating $\mathrm{N}$ demand of a crop should consist of three parts: (a) the calculation of the dry matter production per time; (b) the $\mathrm{N}$ content of this DM; (c) the growth period from sowing/transplanting to physiological/commercial maturity.

A model module for calculating DM production under unstressed conditions based on the light use efficiency approach has been presented (Kage et al. 2001) and was slightly modified regarding the method of light interception calculation (Röhrig \& Stützel 2001). Nitrogen contents of cauliflower organs have been successfully described using empirical functions of organ weight (Kage et al. 2002). An approach for calculating the partitioning of DM between the different plant organs as well as the length of the growth period has been presented (Kage \& Stützel $1999 b$; Kage et al. 2003 a).

These modules for modelling cauliflower growth and development were combined and used to predict the $\mathrm{N}$ demand of cauliflower under varying environmental conditions. Additionally, the effects of limited $\mathrm{N}$ supply on DM production and $\mathrm{N}$ partitioning were included in the model. Such a model is also able to predict the amount of $\mathrm{N}$ in crop residues, which contain more than $50 \%$ of total $\mathrm{N}$ uptake of cauliflower (Rahn et al. 1992; Everaarts et al. 1996). These large $\mathrm{N}$ residues may affect the $\mathrm{N}$ supply of a succeeding crop (Rahn et al. 1998) and/or the possible N-losses through leaching (De Neve \& Hofman 1998) and denitrification (Schloemer 1991).

\section{MATERIAL AND METHODS \\ Field experiments}

The field experiments are essentially the same as described in the first part of this paper. The planting and harvest dates as well as some other important parameters are shown in Table 1. The annual experiments were laid out as split plots with two different light environments, i.e. shaded and unshaded, as main plots and four different nitrogen-fertilizer levels as subplots. In the analysis presented here, only the unshaded treatments are considered. Nitrogen fertilization was given as ammonium nitrate at the time of transplanting. Soil nitrate content $(0-60 \mathrm{~cm})$ of 10 $15 \mathrm{~kg} \mathrm{~N} /$ ha in 1996 and 1997 were subtracted from the $150(\mathrm{~N} 1), 300(\mathrm{~N} 2)$ and $450 \mathrm{~kg} / \mathrm{ha}(\mathrm{N} 3)$ target values. The $\mathrm{N} 0$ treatment received no $\mathrm{N}$ fertilizer.

The experiment at 'Ruthe' is a long-term rotational experiment consisting of two crop rotations, two tillage regimes and two nitrogen fertilization levels with three replications. For the analysis presented here, only data from the mouldboard tillage plots are used. A nitrogen fertilization schedule according to the KNS system (Lorenz et al. 1989) was applied here, defining two target values of $130 \mathrm{~kg} \mathrm{~N} / \mathrm{ha}$ from 0 $30 \mathrm{~cm}$ soil depth at transplanting and of $270 \mathrm{~kg} \mathrm{~N} / \mathrm{ha}$ from $0-60 \mathrm{~cm}$ soil depth about 4 weeks after transplanting. The two $\mathrm{N}$ treatments received either $100 \%$ of this recommended $\mathrm{N}$ supply level or a reduced $\mathrm{N}$ supply of $70 \%$ of this level in 1994 and 1995 and of $50 \%$ of this level in 1996 . The planting density was 4 plants $/ \mathrm{m}^{2}$ in a $0.5 \times 0.5 \mathrm{~m}$ pattern for the spring planting dates and 3.3 plants $/ \mathrm{m}^{2}(0.5 \times 0.6 \mathrm{~m})$ for the summer planting dates. The cultivar 'Fremont' was used in all experiments. General crop husbandry was 
as described in Kage \& Stützel $(1999 b)$ and the first part of the present paper.

Additionally an annual experiment already described (Kage \& Stützel $1999 b$ ) and using two cultivars, 'Linday' and 'Fremont', having different vernalization parameters was used to evaluate developmental effects on $\mathrm{N}$ uptake of cauliflower.

\section{Plant growth analysis}

On several intermediate harvests six plants per plot in the annual experiments and eight plants per plot in the final harvests of the long-term experiment were collected and separated into stem, leaf including petioles, and curd. Leaves larger than $1 \mathrm{~cm}^{2}$ were counted. Stems were cut $1 \mathrm{~cm}$ below the soil surface and below the curd. Leaf area was measured with a LICOR 3100 leaf area meter (LI-COR Inc., Lincoln, NE, USA).

The samples of all plant compartments were oven dried and weighed. In the annual experiment total nitrogen and nitrate nitrogen was determined by the micro-Kjeldahl method (Jones 1991) and a nitrate sensitive electrode (Kolbe et al. 1993), respectively. In the long-term experiment total $\mathrm{N}$ concentrations of plant organs were determined by near-infrared spectrometry (Baker \& Barnes 1990).

\section{Model}

The whole model used in the present study consists of several parts, i.e. algorithms for describing DM partitioning, nitrogen partitioning and DM production. Generally, the model used the following rules:

- Total nitrogen concentrations in cauliflower organs are independent of nitrogen supply rate above a certain critical threshold level.

- Total nitrogen concentrations in cauliflower organs decline during growth because an increasing portion of assimilated carbon is allocated to structural parts of organs.

- The nitrate fraction of leaf $\mathrm{N}$ content under unrestricted nitrogen supply is controlled by the intensity of incident radiation.

- Generative organs have a higher sink priority for nitrogen than vegetative organs.

- Light use efficiency decreases proportionally with increasing differences between optimal and actual protein concentrations per unit leaf area.

\section{Dry matter partitioning}

The DM partitioning part of the model is described in Kage \& Stützel (1999b) and Kage et al. (2003a). However, according to the results of Alt (1999) and Kage et al. (2003a) the development of the sink strength of the curd is delayed for slowly growing crops, caused either by shading or $\mathrm{N}$ deficiency. Therefore, the parameter $r_{f}$ of Eqn (21) from Kage
\& Stützel (1999b), which describes the rapidity of the increase of the fraction of dry matter allocated to the curd, is now assumed to be a function of the average relative growth rate $\overline{r g r}$ during the last 10 days of the vernalization period:

$$
r_{f}=r_{f a} \times \mathrm{e}^{\overline{r g r} \cdot r_{f b}}
$$

The parameters $r_{f a}$ and $r_{f b}$ were estimated from the data 1997 field experiment with $0 \cdot 01$ and $2 \cdot 21$, respectively and were used for all experiments except the annual experiment in 1996 and the late planted 1996 crop of the rotational experiment. For these experiments the values 0.0087 and 7.26 were used for $r_{f a}$ and $r_{f b}$, respectively.

\section{Nitrogen concentrations under sufficient $N$ supply}

An analysis of the dependency of the $\mathrm{N}$ concentration of cauliflower organs under sufficient $\mathrm{N}$ supply was presented (Kage et al. 2002). In the present study the same functional dependencies are used, however, the parameters are derived from the data of the 1996 annual experiment only, to retain a sufficiently large independent data set for the evaluation of the model.

Total leaf $\mathrm{N}$ concentrations of individual leaves under ample $\mathrm{N}$ supply, $\operatorname{NCopt}_{S L}(\% \mathrm{~N} \mathrm{DM})$ are calculated from the weight of individual leaves per plant, $W_{S L}$ (g/plant) and the number of the actual leaf, $i$, using the following equation:

$$
\operatorname{NCopt}_{S L, i}=6.99-0 \cdot 1875 \times W_{S L, i}-0.08 \times i
$$

For derivation of optimal curd nitrogen concentrations $\mathrm{NCopt}_{c}(\% \mathrm{~N} \mathrm{DM})$ the following equation with curd weight $W_{c}$ (g/plant) as independent variable is used:

$$
N \text { Copt }_{c}=6 \cdot 6 \times \mathrm{e}^{\left(-0.0076 \times W_{c}\right)}
$$

The optimal stem nitrogen concentration, NCopt $_{S}(\%$ N DM) is also calculated from the actual weight of the organ, $W_{s}(\mathrm{~g} /$ plant $)$ :

$$
\text { NCopt }_{S}=3 \cdot 45-0 \cdot 346 \times \ln \left(W_{s}\right)
$$

For the tap root an equation from Kage et al. (2002) was used.

$$
N \text { Copt }_{t r}=2.65-0.0381 \times W_{t r}
$$

For the fine root fraction an $\mathrm{N}$ concentration of $1 \%$ in DM was assumed.

\section{Calculation of nitrogen demand}

The optimal $\mathrm{N}$ amount, Nopt, of all plant organs, $i$, from leaf $f_{1}$... leaf $f_{n L}$, curd, stem and tap root is derived from the optimal $\mathrm{N}$ concentration, $\mathrm{NCopt}_{i}(\% \mathrm{~N}$ $\mathrm{DM})$ and their actual weight, $W_{i}(\mathrm{~g} /$ plant $)$ :

$$
\text { Nopt }_{i}=\mathrm{NCopt}_{i} \times W_{i}
$$

Nitrogen demand $N_{d e m}(\mathrm{~g} \mathrm{~N} /$ plant per day) is then determined from the difference of the actual $\mathrm{N}$ 
amount $N_{i}(\mathrm{~g} /$ plant $)$ and the optimal $\mathrm{N}$ amount, Nopt (g N/plant) at the end of the current time step, time step length, $\Delta t$, being 1 day:

$$
N \operatorname{dem}_{i}=\frac{\left(\text { Nopt }_{i}^{t+\Delta t}-N_{i}^{t}\right)}{\Delta t}
$$

The rate of change of the optimal $\mathrm{N}$ concentration of an organ may be calculated from:

$$
\frac{\mathrm{d} N o p t_{i}}{\mathrm{~d} t}=\frac{\mathrm{d} W_{i}}{\mathrm{~d} t} \times\left(N C_{i}+W_{i} \times \frac{\mathrm{d} N \text { Copt }_{i}}{\mathrm{~d} W_{i}}\right)
$$

For leaves, also the nitrate fraction of total leaf $\mathrm{N}$ demand is calculated. Therefore an equation from Kage et al. (2002), also derived from data of the 1996 field experiment, was used:

$$
f_{\mathrm{NO}_{3}}=0 \cdot 2456-0.0023 \times I_{a v}
$$

where $I_{a v}$ is the 10-day running average of radiation intensity incident on a particular leaf. This value is calculated using the sum of the simulated leaf area of all leaves younger than the particular leaf under consideration and Beer's law.

The total $\mathrm{N}$ demand, $\mathrm{Ndem}_{p l}$, is simply the sum of the $\mathrm{N}$ demand of all plant organs:

$$
N \operatorname{dem}_{p l}=\sum N \operatorname{Nem}_{i}
$$

From the $\mathrm{N}$ demand of the leaves and their nitrate fractions the total $\mathrm{N}$ demand of the nitrate pool of the canopy, $\mathrm{Ndem}_{\mathrm{NO}_{3}}(\mathrm{~g} \mathrm{~N} /$ plant per day), is calculated:

$$
\mathrm{Ndem}_{\mathrm{NO}_{3}}=\sum \mathrm{Ndem}_{\mathrm{i}} \times \mathrm{fNO}_{3}
$$

The protein demand of the canopy, Ndem $_{\text {Prot }}$, then simply is the total $\mathrm{N}$ demand minus the leaf nitrate demand:

$$
\mathrm{Ndem}_{\text {Prot }}=\mathrm{Ndem}_{\mathrm{can}}-\mathrm{Ndem}_{\mathrm{NO}_{3}}
$$

Nitrogen remobilization and $\mathrm{N}$-loss due to leaf drop

A certain amount of $\mathrm{N}$ from senescing leaves is remobilized and acts therefore as an additional $\mathrm{N}$ source for the nitrogen demand of other organs. This remobilization rate, $N_{\text {Rem }}$ (g N/plant per day) is calculated from the sum of the senescence rates of all leaves $\mathrm{d} T_{S L W_{i}} / \mathrm{d} t(\mathrm{~g} D \mathrm{DM} /$ plant per day) and the $\mathrm{N}$ concentration of the translocated dry matter $N C_{\text {Trans }}$ (g N/g DM).

$$
N_{\text {Rem }}=N C_{\text {Trans }} \sum_{j=1}^{n_{L}} \frac{\mathrm{d} T_{S L W_{i}}}{\mathrm{~d} t}
$$

The senescence rate is calculated as described in Kage et al. $(2003 a)$ and for $N C_{\text {Trans }}$ a value of $0 \cdot 1$ is assumed, lying between the possible extremes of 0.03 for mature leaves and $0 \cdot 16$ for pure protein. Nitrogenloss due to leaf drop is calculated using the dry weight of the dropped leaves times an assumed residual $\mathrm{N}$ concentration of $0.05 \mathrm{~g} \mathrm{~N} / \mathrm{g} \mathrm{DM}$.

\section{Nitrogen partitioning}

An $\mathrm{N}$ deficit, $N \operatorname{def}$ (g N/plant per day), is calculated by subtracting the maximum uptake rate of the root system $\left(\right.$ Nup $\left._{\max }\right)$, corrected for the planting density, $P D$ (plants $\left./ \mathrm{m}^{2}\right)$, calculated as described in part one of the present study and the amount of $\mathrm{N}$ which is remobilized from senescing leaves (Eqn 13) for the plant $\mathrm{N}$ demand:

$$
N d e f=N d e m-N u p_{\max } / P D-N_{R e m}
$$

Under ample $\mathrm{N}$ supply $(N d e f<0)$, the nitrogen concentration of all organs equals their optimum $\mathrm{N}$ concentrations NCopt $t_{i}$ as described in Eqns (2-5). The change of their $\mathrm{N}$ amount is then calculated by:

$$
\frac{\mathrm{d} N_{i}}{\mathrm{~d} t}=\frac{\mathrm{d} W_{i}}{\mathrm{~d} t}\left(N \operatorname{Copt}_{i}+W_{i} \frac{\mathrm{d} N \operatorname{Copt}_{i}}{\mathrm{~d} W_{i}}\right)
$$

If the actual supply rate is lower than the $\mathrm{N}$ demand $(N d e f>0)$ first the nitrate pool of the leaves is made available for the protein $\mathrm{N}$ demand of the leaves and the $\mathrm{N}$ demand of the other organs. However, transport and assimilation of this nitrate- $\mathrm{N}$ are thought to limit the fraction of available $\mathrm{N}$ from this pool. Simple first order kinetics is used to describe this assumption, calculating a maximum leaf nitrate mobilization rate, $N O_{3 \text { mobmax }}\left(\mathrm{g} \mathrm{N} / \mathrm{m}^{2}\right.$ per day):

$$
\mathrm{NO}_{3 \text { mobmax }}=k_{\mathrm{NO}_{3}} \times \mathrm{NO}_{3} \mathrm{~L}
$$

where $k_{N_{3}}$ (per day) is a parameter determining the rapidity of the mobilization process, set to $0 \cdot 1$ and $\mathrm{NO}_{3} \mathrm{~L}$ is the nitrate pool of the canopy ( $\mathrm{g} \mathrm{N} /$ plant) (Daniel-Vedele et al. 1998).

The change of the leaf nitrate pool then is calculated according to the following equation:

$$
\begin{aligned}
\frac{\mathrm{d} N O_{3} L}{\mathrm{~d} t} & = \begin{cases}N \operatorname{dem}_{\mathrm{NO}_{3}}, & \mathrm{Ndef}<0 \\
\operatorname{Ndem}_{\mathrm{NO}_{3}}-N \text { def }, & N \text { def }-N O_{3 \operatorname{mobmax}} \\
-N O_{3 \text { mobmax }}, & N d e f>N O_{3 \operatorname{mobmax}}\end{cases} \\
& <0
\end{aligned}
$$

If the nitrogen amount available from soil uptake, $\mathrm{N}$ remobilization from senescing leaves and the leaf nitrate pool to satisfy the $\mathrm{N}$ demand of the curd, $N d e m_{\text {curd }}$ (g N/plant per day), then the change of the curd $\mathrm{N}$ amount, $\mathrm{d} N_{\text {curd }} / \mathrm{d} t$ is calculated according to Eqn (15), if less $\mathrm{N}$ is available, all $\mathrm{N}$ is allocated to the curd:

$$
\frac{\mathrm{d} N_{\text {curd }}}{\mathrm{d} t}=\max \left(N \text { dem }_{\text {curd }}, N_{\text {Rem }}+N O_{3 \operatorname{mobmax}}+N u p_{\max }\right)
$$

The change in rate uptake of the $\mathrm{N}$ pools of the other organs, $\mathrm{d} N_{i} / \mathrm{d} t$ (g N/plant per day), is calculated according to the ratio of the remaining available $\mathrm{N}$ to 

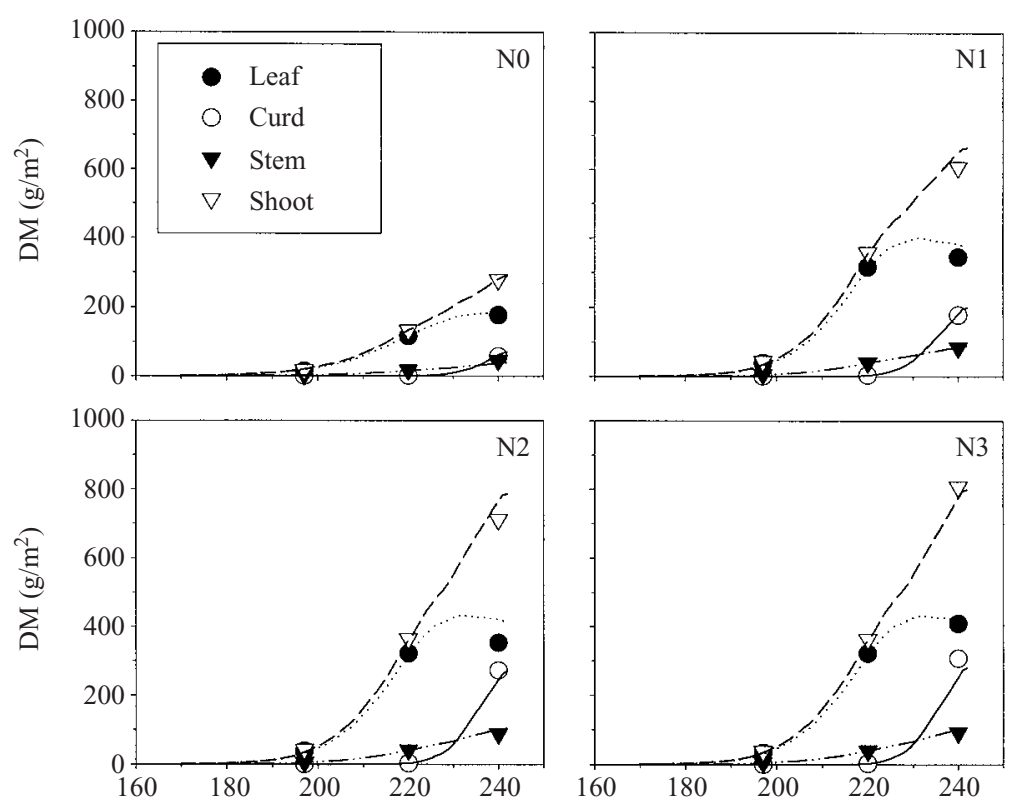

Day of year

Fig. 1. Measured and simulated dry matter production and partitioning of cauliflower under four different $\mathrm{N}$ supplies from the annual experiment in 1996 (parameterization).

their nitrogen demand:

$$
\frac{\mathrm{d} N_{i}}{\mathrm{~d} t}=N \operatorname{Nem}_{i} \frac{N u p_{\max }+N_{\text {Rem }}-\Delta N_{\text {curd }} / \Delta t}{N d e m}
$$

\section{Dry matter production}

The DM production module used in the present study is an extension of the approach described in Kage et al. (2001). Additionally the effect of sub-optimal leaf protein nitrogen concentrations are considered assuming a linear decrease of the light use efficiency, $L U E(\mathrm{~g} / \mathrm{MJ})$ with increasing deviations of leaf protein concentration per area from optimal protein concentrations:

$$
L U E=\left(L U E_{0}-a_{L U E} \times I-b_{L U E}\right) f_{T e m p}
$$

with:

$$
b_{L U E}=N i m p_{L U E} \times\left(N C A o p t_{\text {Prot }}-N C A_{\text {Prot }}\right)
$$

where $N C A$ Apt $t_{\text {Prot }}$ is the average $\mathrm{N}$ concentration of the canopy per canopy area $\left(\mathrm{g}\right.$ protein $\left.\mathrm{N} / \mathrm{m}^{2}\right)$ and $N C A_{\text {Prot }}$ is the actual protein concentration of the canopy. The parameter $\operatorname{Nimp}_{L U E}\left(\mathrm{~g} / \mathrm{MJ} \mathrm{g} \mathrm{N} / \mathrm{m}^{2}\right)$ thereby describes the decrease of $L U E$ with decreasing area based protein nitrogen concentrations.

The parameters $L U E_{0}$ and $N i m p_{L U E}$ were estimated using a part of the experimental data and with a procedure described in the next section. The parameter $a_{L U E}$ was left unchanged at $0.36 \mathrm{~g} \mathrm{DM} \mathrm{m}^{2} \mathrm{~d} /$ $\mathrm{MJ}^{2}$ (Kage et al. 2001).

\section{Parameter estimation and statistics}

The whole model is implemented within the HUME modelling environment (Kage \& Stützel 1999a). This modelling environment supports parameter estimation based on the Marquardt algorithm (Marquardt 1963) and easily allows submodel exchange because of its modular, object-oriented structure. For the present study the parameters $r_{f a}$ and $r_{f b}$ (Eqn 1) were adjusted separately for the 1996 annual together with the late planted 1996 crop from the long-term experiment and all other experiments, respectively. The parameters $L U E_{0}$ (Eqn 20a) Nimp ${ }_{L U E}$ (Eqn $20 b$ ) were estimated for the 1996 and 1997 annual experiments separately. The parameter values obtained from the 1996 experiment then were used for the evaluation of the model using all other data (Table 1).

\section{RESULTS}

The measured dry matter production of the N2 and N3 treatments at the final harvest of the 1996 annual experiment were about $800 \mathrm{~g} / \mathrm{m}^{2}$ and not statistically different (Fig. 1). The DM production of the N1 treatment was only significantly lower than those of the N2 and N3 treatments at the final harvest (Fig. 1).

Estimates for the parameters $L U E_{0}$ and $\operatorname{Nimp}_{L U E}$ of the dry matter production module did not vary considerably for both annual experiments (Table 2). The model described the 1996 dry matter data for different 
Table 2. Estimates of parameters $L U E_{0}(g / M J)$ and $\left(\mathrm{g} / \mathrm{MJ} \mathrm{g} \mathrm{N} / \mathrm{m}^{2}\right)$ from the dry matter production model module as determined from adjustment to data of the both annual experiments

\begin{tabular}{lccc}
\hline \hline Parameter & Year & Value & S.E. \\
\hline LUE $_{\mathbf{0}}$ & 1996 & $6 \cdot 94$ & $0 \cdot 032$ \\
Nimp $_{L U E}$ & 1996 & $0 \cdot 82$ & $0 \cdot 048$ \\
LUE $_{\mathbf{0}}$ & 1997 & $7 \cdot 03$ & $0 \cdot 056$ \\
Nimp $_{L U E}$ & 1997 & $0 \cdot 75$ & $0 \cdot 094$ \\
\hline \hline
\end{tabular}

plant organs almost perfectly (Fig. 1, Table 3). Uptake and partitioning of $\mathrm{N}$ between the plant organs is also described quite well, however, the shoot $\mathrm{N}$ uptake of the N3 treatment was somewhat underestimated. This was mainly caused by curd $\mathrm{N}$ uptake being too low (Fig. 2, Table 3). Leaf nitrate under different $\mathrm{N}$ regimes was described satisfactorily by the model (Fig. 3, Table 3). The model calculated an amount of N-loss due to leaf dropping of about $1 \mathrm{~g}$ $\mathrm{N} / \mathrm{m}^{2}$ for the $\mathrm{N} 2$ and $\mathrm{N} 3$ treatment and a N translocation of about $6 \mathrm{~g} \mathrm{~N} / \mathrm{m}^{2}$ (Fig. 3).

Despite the intensive $\mathrm{N}$ translocation, about twothirds of the shoot $\mathrm{N}$ uptake remains in the unharvested or only partially harvested plant parts stem and leaves (Fig. 2). An additional amount of $\mathrm{N}$ totalling about $10 \%$ of shoot $\mathrm{N}$, remains in the root system (data not shown). Thereby $\mathrm{N}$ harvest index increased with decreasing fertilization rates (Fig. 2).

The model was evaluated using the parameters obtained from the 1996 annual experiment and the data of the 1997 annual experiment as well as data from the long-term field experiment (Table 1). As already indicated by the estimated parameter values shown in Table 2, the model using the parameter values obtained from the 1996 annual experiment underestimated to some extent the dry matter production of the 1997 experiment (Fig. 4). Also the simulated $\mathrm{N}$ uptake of the $\mathrm{N} 2$ and $\mathrm{N} 3$ treatments was lower than the measured values (Fig. 5). The prediction for the whole evaluation data set seems to be less biased (Table 4, Fig. $6 a$ ), but again final values of shoot $\mathrm{N}$ uptake were underestimated to some extent (Fig. 6b). Considerably lower amounts of leaf nitrate were simulated than measured in the 1997 annual experiment (Table 4).

Even for the crops grown under optimal $\mathrm{N}$ supply, there was a large difference of $\mathrm{N}$ uptake at final harvest ranging from about $200 \mathrm{~kg} \mathrm{~N} /$ ha to about $300 \mathrm{~kg}$ $\mathrm{N} /$ ha (Fig. $6 b$ ). This variation, however, is caused by two distinct data subsets, consisting of the spring planted (low $\mathrm{N}$ uptake) and the summer planted (high $\mathrm{N}$ uptake) crops. Much of this variation in $\mathrm{N}$ uptake could be explained due to differences in final leaf number (Fig. 7). Larger numbers of leaves in summer planted crops are thereby caused by delayed vernalization (data not shown). Such differences in numbers of leaves and $\mathrm{N}$ uptake can be even larger for varieties which show a more delayed vernalization at higher temperatures than the cultivar 'Fremont'. Under warm summer conditions the cultivar 'Linday' needed about 27 days for vernalization compared with about 15 days of the cultivar 'Fremont' (Fig. $8 a$ ) and about 9 days under optimal vernalization conditions. The continued leaf initiation during the delayed vernalization phase resulted in final leaf numbers of about 31 for 'Fremont' and 46 for 'Linday' (Fig. 8b), however curd initiation was also delayed and a marketable curd size was reached at a later stage (Fig. 8c). The simulated shoot $\mathrm{N}$ uptake therefore was $32 \mathrm{~g} \mathrm{~N} /$ $\mathrm{m}^{2}$ for cultivar 'Linday' instead of $27 \mathrm{~g} \mathrm{~N} / \mathrm{m}^{2}$ for cultivar 'Fremont' at a similar curd $\mathrm{N}$ uptake of $8.2 \mathrm{~g}$ $\mathrm{N} / \mathrm{m}^{2}$ (Fig. $8 d$ ).

The temperature conditions presented in Fig. $8 a$ are at the higher range of values which are typical for northern Germany. However, even under the quite maritime climatic conditions of this location a quite substantial variation of $\mathrm{N}$ uptake at curd maturity between different planting dates and for the both cultivars 'Fremont' and 'Linday' over period of 20 years was calculated (Fig. 9). For the cultivar 'Fremont' average value for $\mathrm{N}$ uptake of the shoot ranging from about $25 \mathrm{~g} \mathrm{~N} / \mathrm{m}^{2}$ for early planting dates up to $29 \mathrm{~g} \mathrm{~N} / \mathrm{m}^{2}$ for late planting dates were simulated (Fig. 9). Exceptionally for the last planting date, calculated standard deviation of $\mathrm{N}$ uptake was at around $2.5 \mathrm{~g} \mathrm{~N} / \mathrm{m}^{2}$ (Fig. 9). For the cultivar 'Linday', however, the calculated average values of shoot $\mathrm{N}$ uptake were only slightly higher for early planting dates, but exceeded the average values of 'Fremont' by up to $2.5 \mathrm{~g} \mathrm{~N} / \mathrm{m}^{2}$ for summer plantings (Fig. 9). Also the calculated standard deviation of $\mathrm{N}$ uptake was higher for this cultivar with values from 2.9 to $3.4 \mathrm{~g} \mathrm{~N} / \mathrm{m}^{2}$ (Fig. 9). About $2 \cdot 5-4 \cdot 5 \mathrm{~g} / \mathrm{m}^{2}$ of shoot $\mathrm{N}$ is calculated to be situated within the leaf nitrate pool (Fig. 9).

A scenario calculation was carried out to obtain $\mathrm{N}$ response curves for DM production and shoot $\mathrm{N}$ uptake. The obtained response curves for shoot DM are characterized by a higher DM yield at zero $\mathrm{N}$ fertilization for the loess loam soil and a more rapid approach to maximum DM yield for the loess loam soil compared to the sandy soil (Fig. 10a). A split application of nitrogen on the sandy soil only partly reduced the differences between both soils. $\mathrm{N}$ uptake of cauliflower shoots responds more linearly to an increased $\mathrm{N}$ supply than dry matter (Fig. 10b) but the differences between the soil types and the single and split application on the sandy soil are similar.

\section{DISCUSSION}

The present study aims to quantify dry matter production and $\mathrm{N}$ uptake and partitioning of cauliflower crops grown under varying climatic conditions and 
Table 3. Results of linear regression analysis (slope, intercept, $\mathrm{R}^{2}, \mathrm{n}$ ) as well as the residual mean square error and the modelling efficiency for a number of state variables (DM: dry matter in $\mathrm{g} / \mathrm{m}^{2}, N$ : amount of $N$ in $\mathrm{g} / \mathrm{m}^{2}$ ) from the parameterization of the model using the data of the 1996 annual field experiment

\begin{tabular}{|c|c|c|c|c|c|c|}
\hline Parameter & Slope & Intercept & $R^{2}$ & $n$ & RMSE & $\mathrm{EF}$ \\
\hline DM Leaf & $0 \cdot 9161$ & $10 \cdot 1445$ & 0.9854 & 12 & $23 \cdot 2950$ & 0.9742 \\
\hline DM Curd & $1 \cdot 1433$ & -3.9892 & 0.9886 & 8 & $22 \cdot 1058$ & $0 \cdot 9671$ \\
\hline DM Stem & $0 \cdot 8964$ & $3 \cdot 1760$ & 0.9860 & 12 & $5 \cdot 4007$ & 0.9720 \\
\hline DM Shoot & 0.9678 & $7 \cdot 7180$ & 0.9937 & 12 & $22 \cdot 8977$ & 0.9925 \\
\hline LAI & $1 \cdot 0054$ & $-0 \cdot 1231$ & 0.9755 & 12 & $0 \cdot 2536$ & 0.9696 \\
\hline N Leaf & $1 \cdot 0188$ & -0.0276 & 0.9891 & 12 & 0.6085 & $0 \cdot 9884$ \\
\hline Leaf nitrate & 0.9943 & $0 \cdot 0240$ & 0.9334 & 12 & $0 \cdot 2372$ & 0.9329 \\
\hline N Curd & 0.9260 & 0.0551 & 0.9825 & 12 & $0 \cdot 1051$ & 0.9763 \\
\hline N Stem & $1 \cdot 2739$ & $-0 \cdot 3244$ & $0 \cdot 9855$ & 8 & $1 \cdot 2348$ & 0.9277 \\
\hline N Shoot & 1.0895 & $-0 \cdot 3083$ & 0.9920 & 12 & $1 \cdot 2658$ & 0.9814 \\
\hline
\end{tabular}
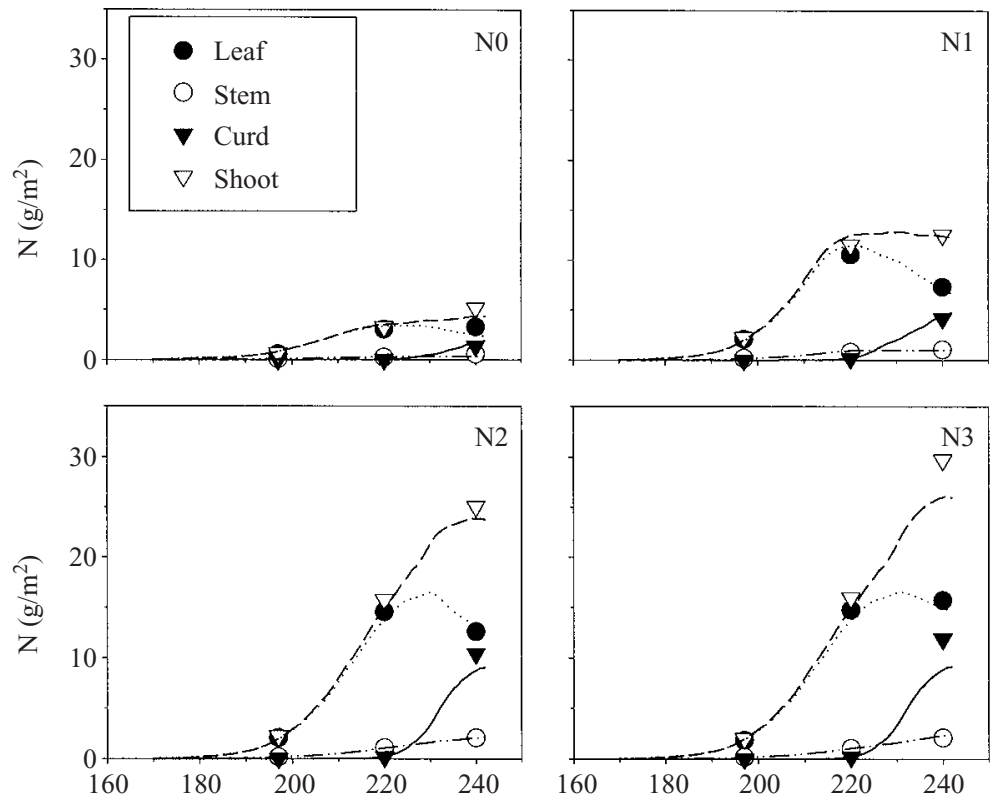

Day of year

Fig. 2. Measured and simulated $\mathrm{N}$ uptake and partitioning of cauliflower under four different $\mathrm{N}$ supplies from the annual experiment in 1996 (parameterization).

nitrogen supply. This may facilitate more precise $\mathrm{N}$ fertilizer recommendations and thereby help to minimize potential harmful leaching of nitrate into the groundwater.

The simple $L U E$ based approach for calculating dry matter production was quite successful in describing (Fig. 1, Table 3) and predicting (Fig. 4, Table 4) dry matter production of cauliflower under a varied $\mathrm{N}$ supply. The influence of protein $\mathrm{N}$ concentration per leaf area on light use efficiency is depicted in the presented model with a kind of a linear response plateau approach, because the linear increase of $L U E$ with a increasing $N C A_{\text {Prot }}$ from sub-optimal values (Eqn 20) is cut off by the upper limit of $N C A_{\text {Prot }}$ resulting from Eqns (2) and (8). Non-linear saturating response functions of $L U E$ on $N C A_{\text {Prot }}$ (Sinclair \& Horie 1989; Muchow \& Sinclair 1994; Bange et al. 1997) may be more realistic. Generally, canopy aggregated $L U E$ approaches are not able to predict effects of a changing $\mathrm{N}$ distribution within the canopy (Hirose $\&$ Werger 1987; Bindraban 1999). Theoretical studies indicate a large effect of $\mathrm{N}$ distribution on the functional relationship between $L U E$ and $N C A_{\text {Prot }}$ (Alt et al. 2000). However, the $\mathrm{N}$ distribution within the canopy of cauliflower seems not to be seriously influenced by either $\mathrm{N}$ deficiency or radiation intensity (Kage et al. 

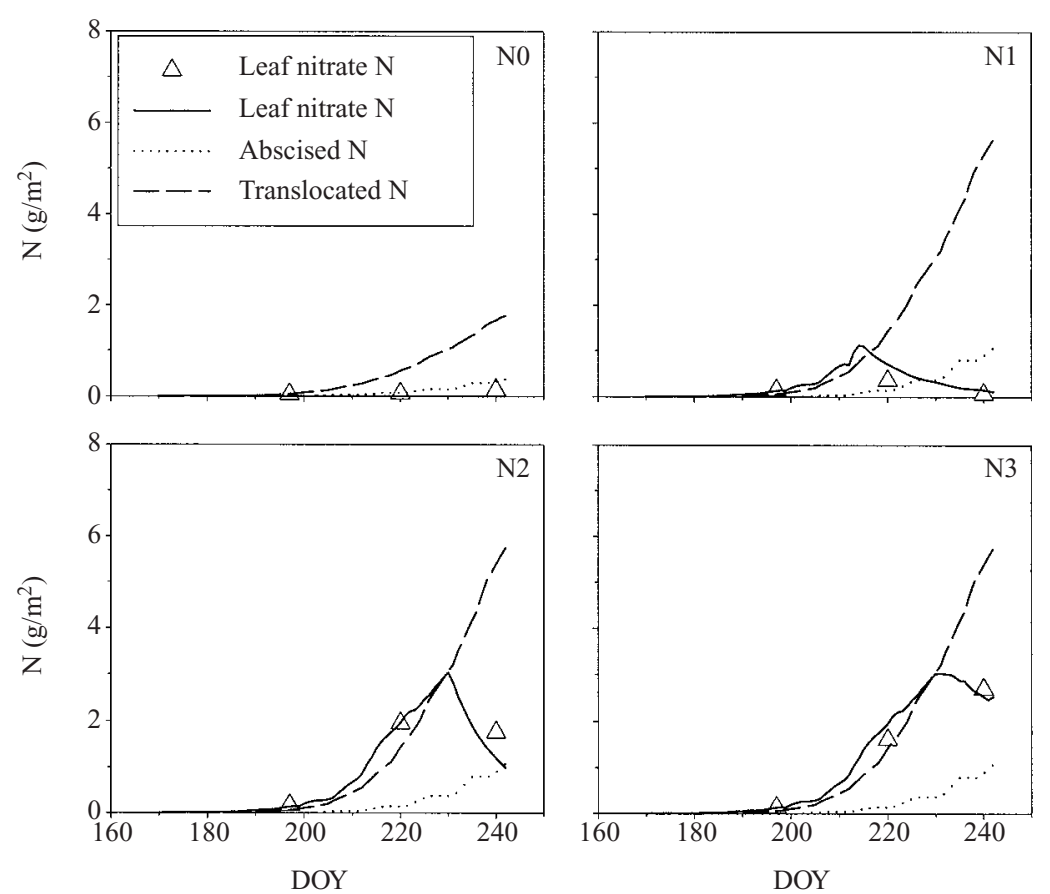

Fig. 3. Simulated and measured leaf nitrate content as well as simulated cumulative N-loss due to leaf drop and cumulative leaf $\mathrm{N}$ translocation for the 1996 annual experiment.
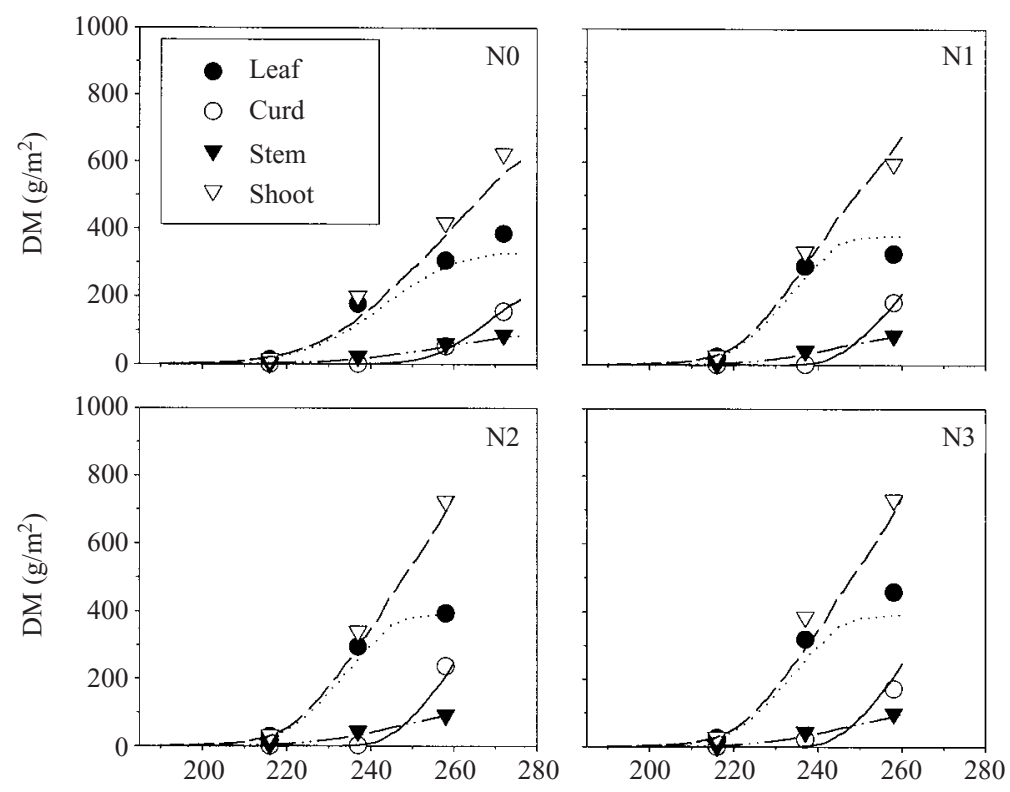

Day of year

Fig. 4. Measured and simulated dry matter production and partitioning of cauliflower under four different $\mathrm{N}$ supplies from the annual experiment in 1997 (evaluation). 
Table 4. Results of linear regression analysis (slope, intercept, $\mathrm{R}^{2}, \mathrm{n}$ ) as well as the residual mean square error (RMSE) and the modelling efficiency $(E F)$ for a number of state variables (DM: dry matter in $\mathrm{g} / \mathrm{m}^{2}, \mathrm{~N}$ : amount of $N$ in $\left.\mathrm{g} / \mathrm{m}^{2}\right)$ from the evaluation of the model using the data of the 1997 annual field experiment and of six crops from the long-term experiment (see Table 1)

\begin{tabular}{|c|c|c|c|c|c|c|}
\hline Parameter & Slope & Intercept & $R^{2}$ & $n$ & RMSE & $\mathrm{EF}$ \\
\hline DM Leaf & 0.9956 & $13 \cdot 9984$ & $0 \cdot 9116$ & 51 & $62 \cdot 1031$ & 0.9076 \\
\hline DM Stem & 0.9241 & $4 \cdot 4996$ & 0.6683 & 51 & $27 \cdot 2220$ & 0.6634 \\
\hline DM Curd & $1 \cdot 1044$ & $2 \cdot 0846$ & $0 \cdot 8293$ & 35 & $41 \cdot 9739$ & $0 \cdot 8104$ \\
\hline DM Shoot & 1.0357 & $7 \cdot 5372$ & $0 \cdot 9530$ & 51 & $72 \cdot 0527$ & 0.9477 \\
\hline LAI & 1.0312 & $0 \cdot 2490$ & $0 \cdot 8328$ & 42 & 0.9611 & $0 \cdot 8091$ \\
\hline N Leaf & $1 \cdot 0585$ & $-0 \cdot 3842$ & $0 \cdot 8833$ & 51 & $2 \cdot 0622$ & $0 \cdot 8805$ \\
\hline Leaf nitrate & 1.7691 & $0 \cdot 1739$ & 0.9398 & 12 & $1 \cdot 6130$ & $0 \cdot 5904$ \\
\hline N Stem & $0 \cdot 8457$ & $0 \cdot 1202$ & $0 \cdot 7471$ & 51 & $0 \cdot 3874$ & 0.7217 \\
\hline N Curd & 0.9246 & $-0 \cdot 1824$ & $0 \cdot 8156$ & 31 & $1 \cdot 3815$ & 0.7871 \\
\hline N Shoot & 1.0239 & -0.3814 & $0 \cdot 9240$ & 51 & $2 \cdot 3635$ & 0.9233 \\
\hline
\end{tabular}
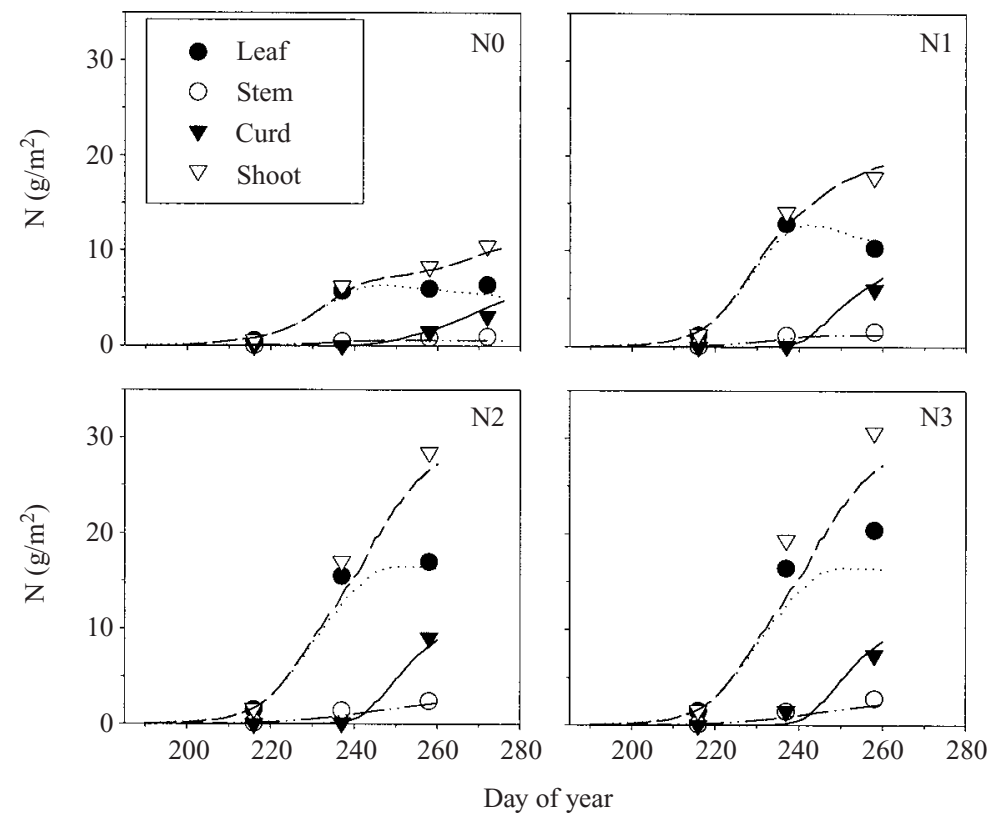

Fig. 5. Measured and simulated $\mathrm{N}$ uptake and partitioning of cauliflower under four different $\mathrm{N}$ supplies from the annual experiment in 1997 (evaluation).

2002). This may explain the quite satisfying predictive quality of the LUE approach presented in the current paper.

The estimated values of $L U E_{0}$ (Table 2) are somewhat lower than reported in Kage et al. (2003a). This may partly be caused by the use of a modified light interception module described in Kage et al. (2003a), which takes a value of 0.75 for the extinction coefficient for photosynthetic radiation instead of 0.65 used in Kage et al. (2000). More recently, Olesen \& Grevsen (2000) published a $L U E$ approach for calculating dry matter production also assuming a linear decrease of $L U E$ with increasing levels of radiation intensity. Their value of $L U E_{0}$ is much lower $(5.44 \mathrm{~g} /$ MJ) but they assumed only a slightly decrease of $L U E$ with PAR resulting in very similar predictions of both approaches at daily radiation levels of about 6-7 MJ $\mathrm{PAR} / \mathrm{m}^{2}$ per day.

Adjusted initial values for shoot dry matter were used for the early plantings of the rotational experiment. The reasons for this procedure have been discussed in Kage et al. (2001). Briefly, the model has problems predicting dry matter production of early plantings because the leaf area loss due to frost and the sometimes severe transplanting shock are not considered in the model. This shortcoming may be 

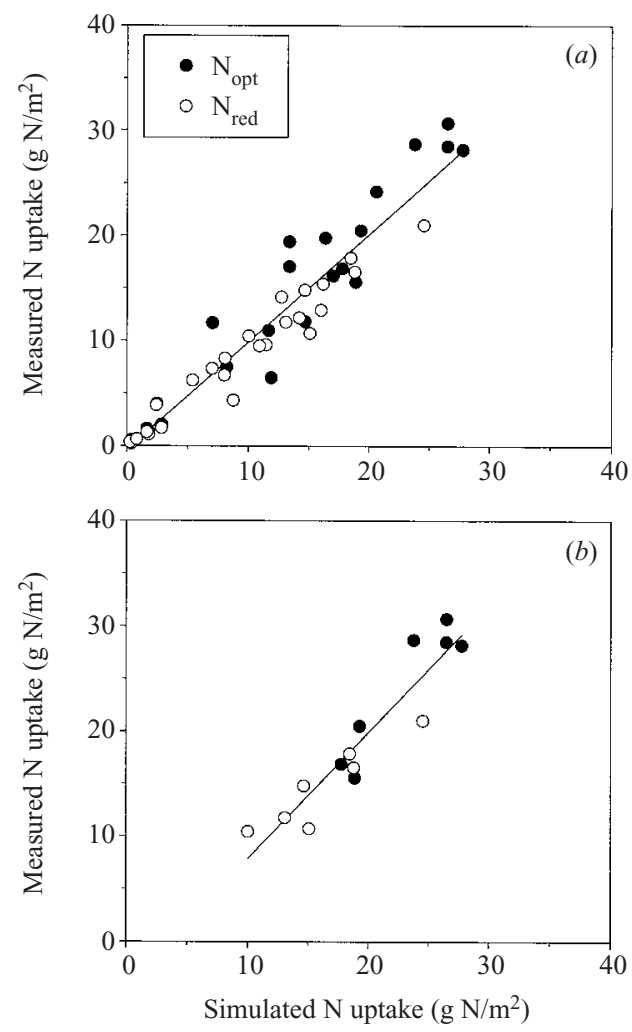

Fig. 6. Measured and simulated shoot $\mathrm{N}$ uptake of cauliflower under different supplies, grouped into optimal $\mathrm{N}$ supply (Nopt) and reduced N supply (Nred). Figure ( $a$ ) is for all harvests, and $(b)$ only for final harvests. For parameters of the regression lines shown in $(a)$ see Table 4 , for (b): $y=-4 \cdot 192( \pm 2 \cdot 68)+1 \cdot 20( \pm 0 \cdot 13) x, R^{2}=0 \cdot 87, n=14$. All evaluation experiments except the 1994 annual experiment were used.

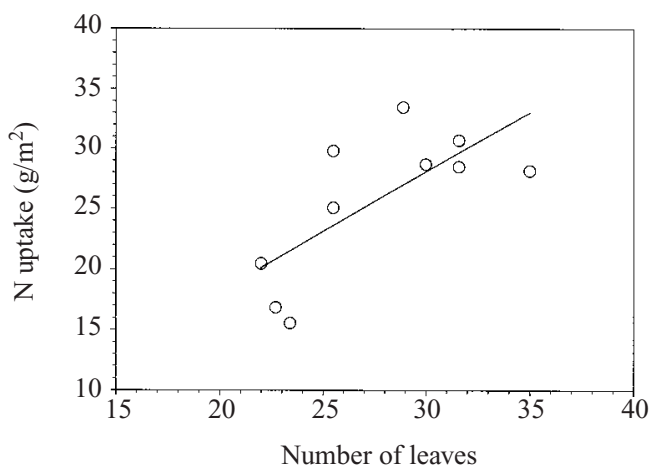

Fig. 7. Relationship between simulated final leaf number and measured shoot $\mathrm{N}$ uptake for cauliflower crops grown under high $\mathrm{N}$ supply. The linear regression equation shown is $y=-1.64( \pm 9 \cdot 43)+0.99( \pm 0.34) x, R^{2}=0 \cdot 52, n=10$.
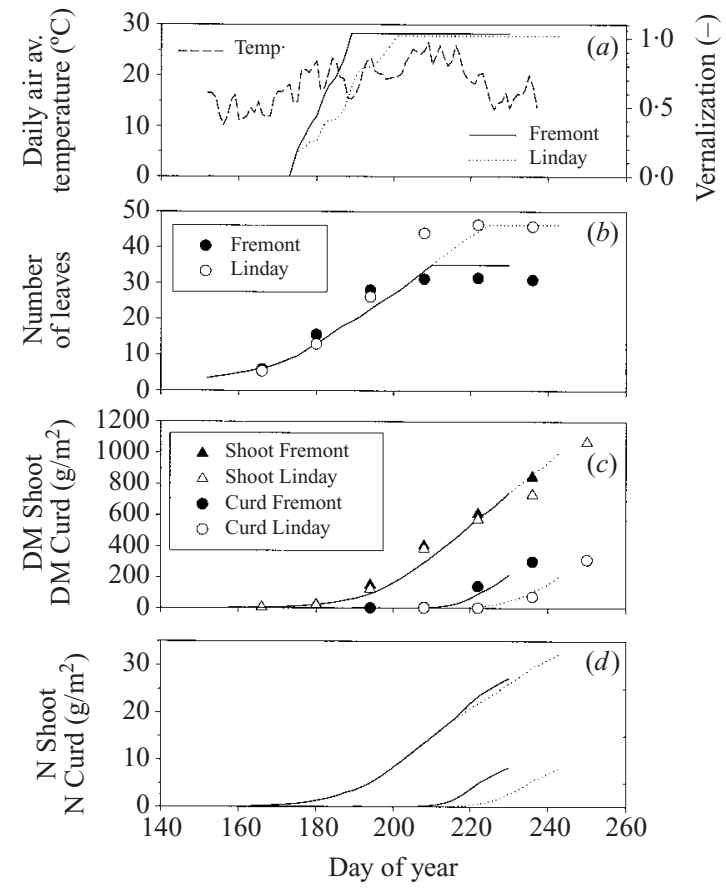

Fig. 8. Daily average air temperature, simulated vernalization state $(a)$, measured and simulated number of visible leaves $(b)$, measured and simulated shoot and curd dry matter $(c)$ and simulated shoot and curd nitrogen for a field experiment with two cauliflower cultivars ('Fremont' and 'Linday') carried out in 1994.

handled by initializing the model and starting the simulation after complete establishment of the crop and not at transplanting.

The reasons for the different rapidity of curd growth for the later planted crops in 1996 are still not clear. There seems to be an influence of assimilate supply on curd initiation and/or growth. This is described by Alt (1999) with a function enhancing curd sink size more rapidly with higher values of leaf $\mathrm{N}$ per leaf area. Nowbuth \& Pearson (1998) found an influence of assimilated supply on curd initiation. However, there was no indication of such an influence which should affect final leaf number in the present experiments (Kage et al. 2003a). Further research is therefore needed to address this problem more thoroughly.

The results presented in Fig. 3 demonstrate the high amount of leaf nitrate in cauliflower plants accumulated under high $\mathrm{N}$ supply and indicate a high importance of $\mathrm{N}$ translocation from senescing leaves to younger plant parts during the later growth stage of cauliflower. The latter result, however, relies on estimates about the onset of leaf senescence (Kage et al. $2003 a$ ) and measured $\mathrm{N}$ concentrations of senescent leaves. Direct measurements of $\mathrm{N}$ translocation using isotopes (Ma et al. 1998) or of leaf $\mathrm{N}$ concentration 

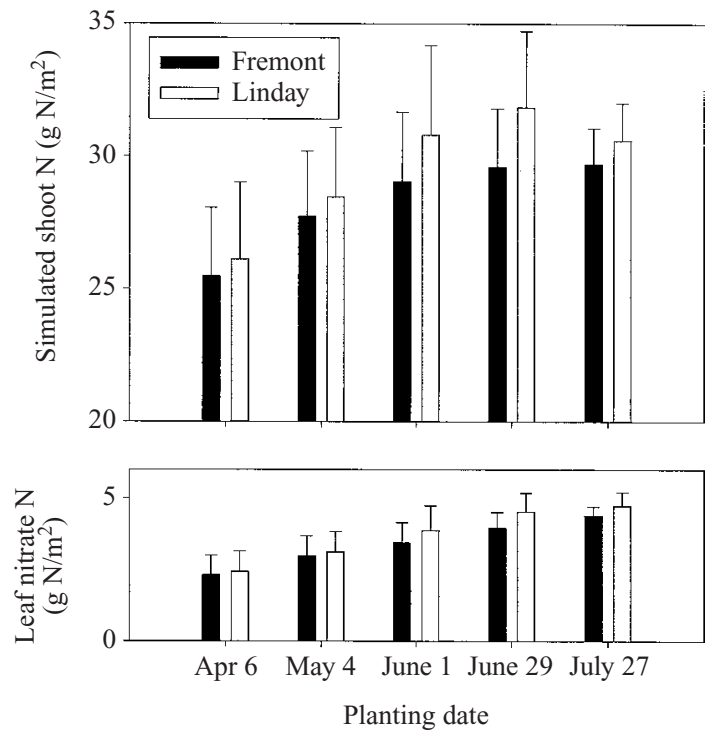

Fig. 9. Simulated shoot $\mathrm{N}$ and leaf nitrate $\mathrm{N}$ at curd maturity (marketable size: $180 \mathrm{~mm}$ diameter) of two different cauliflower cultivars ('Fremont', 'Linday') for different planting dates calculated over a time period of 20 years using weather data from Hannover, Germany. Error bars indicate the standard error.

with high temporal resolution may be used to further substantiate the estimates presented in the present paper.

The low nitrogen harvest index (Figs 2 and 5) of cauliflower observed in the present study is in accordance with other data from the literature (Rahn et al. 1992; Everaarts et al. 1996; Greenwood et al. 1996; Van den Boogaard \& Thorup-Kristensen 1997). Low values of $\mathrm{N}$ harvest index are common for vegetable crops where immature generative organs are harvested, like brussels sprouts (Booij et al. 1997) and broccoli (Bowen et al. 1999). For late harvested crops these large amounts of $\mathrm{N}$ in crop residues represent a substantial leaching risk (De Neve \& Hofman 1998).

The calculated relatively small effect of the split nitrogen application (Fig. 10) on shoot dry matter and shoot $\mathrm{N}$ uptake is in accordance with results of Everaarts et al. (1996). It can be explained by the dominating effect of soil water contents on the differences in uptake efficiency between the sandy and the loess loam soil and by the absence of N-losses due to leaching out of the rooted soil volume. The response of $\mathrm{N}$ uptake to increasing $\mathrm{N}$ supply is similar to a linear response-plateau, with two segments of the linear phase. The second segment of the linear phase with a smaller slope results from the fact that increasing portions of the $\mathrm{N}$ uptake are calculated to be allocated to the nitrate fraction, which the model considers as not productive. The plateau level clearly is the consequence of the saturated sink capacity of

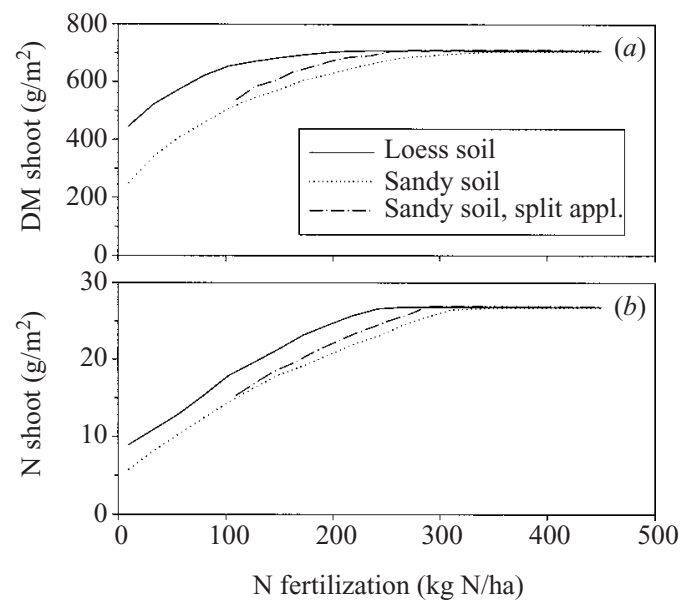

Fig. 10. Simulated shoot dry matter and shoot nitrogen under varying nitrogen fertilization rates for a loess loam soil, a sandy soil and a sandy soil with split $\mathrm{N}$ application. All other input variables as in the 1997 annual experiment.

the cauliflower crop. Greenwood et al. (1989) compared the $\mathrm{N}$ response of vegetable and gramineous crops and found a linear response-plateau response more typical for gramineous than for vegetable crops where quadratic response function gave a better fit to the data. He interpreted this as the consequence of a restricted $\mathrm{N}$ availability especially during early growth stages of vegetable crops, where rooting density is much lower than for gramineous crops. Thereby $\mathrm{N}$ application rates exceeding the $\mathrm{N}$ demand of the shoot are still increasing crop productivity of vegetables by increasing the $\mathrm{N}$ availability at early growth stages. The model approach used in the present study did not calculate such a limitation of $\mathrm{N}$ availability during early growth stages (Fig. 7, first part of this paper), but this may be due to the neglect of the spatial heterogeneity of the root system during early growth stages of cauliflower.

The presented results can be used to implement a more specific $\mathrm{N}$ fertilization recommendation system for cauliflower. Summer planted crops generally seem to have a $30-40 \mathrm{~kg} \mathrm{~N} /$ ha higher $\mathrm{N}$ demand and show a higher variation of $\mathrm{N}$ demand because of variations in vernalization time. Because daily mineralization rates are usually substantially lower than crop $\mathrm{N}$ uptake this causes an increased demand for fertilizer $\mathrm{N}$. The model approach presented in the present study is able to quantify this additional $\mathrm{N}$ demand and to adjust a second $\mathrm{N}$ application immediately after completion of the vernalization (Fig. 8). Further development is needed to include suitable estimations of net mineralization into the model calculations.

There is a discrepancy between the fertilization recommendations between several countries in Western Europe. Whereas Everaarts et al. (1996) recommends 
a target value of $224 \mathrm{~kg} \mathrm{~N} / \mathrm{ha}$ minus soil nitrate from $0-60 \mathrm{~cm}$ at planting, based on experiments in the Netherlands, the KNS system advises higher values of $270 \mathrm{~kg} \mathrm{~N} /$ ha 4 weeks after planting (Lorenz et al. 1989), equivalent to about $300 \mathrm{~kg} \mathrm{~N} /$ ha at planting. Some of these differences may be explained by differing soil conditions including differing typical mineralization rates. However, a contribution of a higher vernalization risk at more continental climates may be included in the German recommendations.

\section{CONCLUSIONS}

The observed and predicted differences in shoot $\mathrm{N}$ content at curd maturity (Figs 6 and 9) give indications for a specific $\mathrm{N}$ fertilization regime for different (a) climatic conditions, (b) cultivars and (c) soil types. Summer planted crops with a usually increased number of leaves take up about $30-40 \mathrm{~kg} \mathrm{~N} /$ ha more than early-planted crops. A better adaptation of $\mathrm{N}$ fertilization and $\mathrm{N}$ demand of cauliflower may be achieved by split application of $\mathrm{N}$. A second $\mathrm{N}$ fertilization after the end of the vernalization period should be increased after periods of high temperatures resulting in an increased number of leaves and a longer growth period. For sandy soils a somewhat higher level of soil nitrate is needed to sustain maximum growth rates. On this soil type, split nitrogen applications may also marginally enhance nitrogen availability and partly reduce $\mathrm{N}$ leaching losses.

\section{REFERENCES}

Alt, C. (1999). Modelling nitrogen demand in cauliflower (Brassica oleracea L. botrytis) using productivity-nitrogen relationships. Ph.D. thesis, University of Hannover, Hannover. http://edok01.tib.uni-hannover.de/edoks/ e002/2699152571.pdf

Alt, C., Stützel, H. \& Kage, H. (2000). Optimal nitrogen content and photosynthesis in cauliflower (Brassica oleracea L. botrytis). Scaling up from a leaf to the whole plant. Annals of Botany 85, 779-787.

BAKER, C. W. \& BARNES, R. (1990). The application of near infraed spectrosmetry of forage evaluation in the Agricultural Development and Advisory Service. In Feedstuff Evaluation (Eds J. Wiseman \& D. J. A. Cole), pp. 337351. London: Butterworths.

Bange, M. P., Hammer, G. L. \& Rickert, K. G. (1997). Effect of specific leaf nitrogen on radiation use efficiency and growth of sunflower. Crop Science 37, 1201-1207.

BindRABAN, P. S. (1999). Impact of canopy nitrogen profile in wheat on growth. Field Crops Research 63, 63-77.

Booij, R., Kreuzer, A. D. H., Smit, A. L. \& Van Der WERF, A. (1997). Effects of nitrogen availability on the biomass and nitrogen partitioning in Brussels sprouts (Brassica oleracea var. gemmifera). Journal of Horticultural Science 12, 285-291.

Bowen, P. A., Zebarth, B. J. \& Toivonen, P. M. A. (1999). Dynamics of nitrogen and dry-matter partitioning and accumulation in broccoli (Brassica oleracea var. italica) in relation to extractable soil inorganic nitrogen. Canadian Journal of Plant Science 79, 277-286.

Daniel-Vedele, F., Filleur, S. \& Caboche, M. (1998). Nitrate transport: a key step in nitrate assimilation. Current Opinions in Plant Biology 1, 235-239.

De Neve, S. \& Hofman, G. (1998). N mineralization and nitrate leaching from vegetable crop residues under field conditions: a model evaluation. Soil Biology \& Biochemistry 30, 2067-2075.

Everaarts, A. P. \& Van den Berg, W. (1996). A comparison of three nitrogen response models for cauliflower. Acta Horticulturae 428, 171-179.

Everaarts, A. P., De Moel, C. P. \& Van Noordwijk, M. (1996). The effect of nitrogen and the method of application on nitrogen uptake of cauliflower and on nitrogen in crop residues and soil at harvest. Netherlands Journal of Agricultural Science 44, 43-55.
Greenwood, D. J., Kubo, K., Burns, I. G. \& Draycott, A. (1989). Apparent recovery of fertilizer N by vegetable crops. Soil Science and Plant Nutrition 35, 367-381.

Greenwood, D. J., Rahn, C., Draycott, A., Vaidyanathan, L. V. \& Paterson, C. (1996). Modelling and measurement of the effects of fertilizer- $\mathrm{N}$ and crop residue incorporation on $\mathrm{N}$-dynamics in vegetable cropping. Soil Use and Management 12, 13-24.

Hirose, T. \& Werger, M. J. A. (1987). Maximizing daily canopy photosynthesis with respect to the leaf nitrogen allocation pattern in the canopy. Oecologia 72, 520-526.

Jones, J. B. (1991). Kjeldahl Method for Nitrogen (N) Determination. Athens, GA: Micro-Macro Publishing.

Kage, H. \& Stützel, H. (1999a). HUME: An object oriented component library for generic modular modelling of dynamic systems. In Modelling Cropping Systems (Eds C. S. M. Donatelli, F. Villalobos \& J. M. Villar), pp. 299-300. Lleida, Spain: European Society for Agronomy.

Kage, H. \& StÜtzel, H. (1999b). A simple empirical model for predicting development and dry matter partitioning in cauliflower (Brassica oleracea L. botrytis). Scientia Horticulturae 80, 19-38.

Kage, H., Kochler, M. \& Stützel, H. (2000). Root growth of cauliflower (Brassica oleracea L. botrytis) under unstressed conditions: measurement and modelling. Plant and Soil 223, 133-147.

Kage, H., Alt, C. \& Stützel, H. (2001). Predicting dry matter production of cauliflower (Brassica oleracea L. botrytis) under unstressed conditions II. Comparison of light use efficiency and photosynthesis-respiration based model modules. Scientia Horticulturae 87, 171-190.

Kage, H., Alt, C. \& Stützel, H. (2002). Nitrogen concentration of cauliflower organs as determined by organ size, $\mathrm{N}$ supply and radiation environment. Plant and Soil 246, 201-209.

Kage, H., Kochler, M., Alt, C. \& Stützel, H. (2003a). Predicting dry matter partitioning between individual cauliflower leaves using a source limitation/sink hierarchy approach. Jounal of Horticultural Science \& Biotechnology 78, 549-553.

Kage, H., Alt, C. \& Stützel, H. (2003b). Aspects of nitrogen use efficiency of cauliflower I. A simulation 
modelling based analysis of nitrogen availability under field conditions. Journal of Agricultural Sciences, Cambridge 141, 1-16.

Kolbe, H., Zhang, W. L., Schaerer, H., Wathsack, T. \& Kuensch, U. (1993). Nitrate determination in plant, mushroom, and algae species with an ion-selective electrode. Agrobiological Research 46, 89-99.

Lorenz, H.-P., Schlaghecken, J., Engl, G., Maync, A. \& ZIEGLER, J. (1989). Ordnungsgemäße Stickstoff-Versorgung im Freiland-Gemüsebau nach dem kulturbegleitenden Nmin-Sollwerte-(KNS) System. Rheinland-Pfalz, Germany: Ministerium für Landwirtschaft, Weinbau und Forsten.

Ma, B. L., Dwyer, L. M., Tollenaar, M. \& Smith, D. L. (1998). Stem infusion of nitrogen-15 to quantify nitrogen remobilization in maize. Communications in Soil Science and Plant Analysis 29, 305-317.

Marquardt, D. W. (1963). An algorithm for least-squares estimation of nonlinear parameters. Journal of the Society of Industrial and Applied Mathmatics 11, 431-441.

Muchow, R. C. \& Sinclair, T. R. (1994). Nitrogen response of leaf photosynthesis and canopy radiation use efficiency in field-grown maize and sorghum. Crop Science 34, 721-727.

Nowbuth, R. D. \& Pearson, S. (1998). The effect of temperature and shade on curd initiation in temperature and tropical cauliflower. Acta Horticulturae 459, $79-87$.

Olesen, J. E. \& Grevsen, K. (2000). A simulation model of climate effects on plant productivity and variability in cauliflower (Brassica oleracea L. botrytis). Scientia Horticulturae 83, 83-107.

Rahn, C. R., Vaidyanathan, L. V. \& Paterson, C. D. (1992). Nitrogen residues from brassica crops. Aspects of Applied Biology 30, 263-270.
Rahn, C. R., Paterson, C. D. \& Vaidyanathan, L. V. (1998). The use of measurements of soil mineral $\mathrm{N}$ in understanding the response of crops to fertilizer nitrogen in intensive cropping rotations. Journal of Agricultural Science, Cambridge 130, 345-356.

Röhrig, M. \& Stützel, H. (2001). A model for light competition between vegetable crops and weeds. European Journal of Agronomy 14, 13-29.

Scharpf, H. C. \& Wehrmann, J. (1975). Bedeutung des Mineralstoffvorrates des Bodens zu Vegetationsbeginn für die Bemessung der N-Düngung zu Winterweizen. Landwirtschaftliche Forschung, Sonderheft 32, 100-114.

Schloemer, S. (1991). Denitrifikation eines gemüsebaulich genutzten Bodens in Abhängigkeit von der Einarbeitung frischer Erntereste. Zeitschrift Pflanzenernährung und Bodenkunde 154, 265-269.

Sinclair, T. R. \& Horie, T. (1989). Leaf nitrogen, photosynthesis, and crop radiation use efficiency: a review. Crop Science 29, 90-98.

Stockdale, E. A., Gaunt, J. L. \& Vos, J. (1997). Soil-plant nitrogen dynamics: what concepts are required? European Journal of Agronomy 7, 145-159.

VAn den Boogatrd, R. \& Thorup-Kristensen, K. (1997). Effects of nitrogen fertilization on growth and soil nitrogen depletion in cauliflower. Acta Agriculturae Scandinavica Section B, Soil and Plant Science 47, 149-155.

Wiebe, H.-J. (1980). Anbau von Blumenkohl für eine kontinuierliche Marktbelieferung während der Erntesaison. Gartenbauwissenschaft 45, 282-288.

Wurr, D. C. E., Fellows, J. R., Phelps, K. \& Reader, R. J. (1994). Testing a vernalization model on field-grown crops of four cauliflower cultivars. Journal of Horticultural Science 69, 251-255. 